\title{
A Lexicographic Approach to Language Policy and Recommen- dations for Future Dictionaries
}

\author{
Sven Tarp, Centre for Lexicography, Aarhus School of Business, University of \\ Aarhus, Aarhus, Denmark (st@asb.dk) \\ and \\ Rufus H. Gouws, Department of Afrikaans and Dutch, University of \\ Stellenbosch, Stellenbosch, Republic of South Africa (rhg@sun.ac.za)
}

\begin{abstract}
Language policy prevails at different levels and its formulation typically results in a prescriptive presentation of data. In their dictionaries, lexicographers have to respond to the decisions of language policy makers. In this regard dictionaries can adhere to a strict prescriptive policy by including only the prescribed forms. Dictionaries can also give a descriptive account of language use without making any recommendations or claims of correctness. Thirdly, dictionaries can be proscriptive by recommending certain forms, even if such a recommendation goes against the prescribed forms. This article offers an overview of different levels of language policy and the principles of prescription, description and proscription. Examples are given to illustrate certain lexicographic applications of prescription. It is emphasised that access to relevant data is important to dictionary users. Consequently the lexicographic application of proscription is discussed as a viable alternative to prescription. It is suggested that proscription, in its different possible applications, can lead to a lexicographic presentation that benefits the user and that contributes to the satisfaction of the functions of a given dictionary.
\end{abstract}

Keywords: ACCESS, COGNITIVE FUNCTION, COMPLEMENTARY PROSCRIPTION, DESCRIPTION, DIRECT PRESCRIPTION, DIRECT PROSCRIPTION, DOMAIN-SPECIFIC LANGUAGE POLICY, INDIRECT PRESCRIPTION, INDIRECT PROSCRIPTION, LANGUAGE POLICY, LEVELS OF LANGUAGE POLICY, LEXICOGRAPHIC FUNCTIONS, NATIONAL LANGUAGE POLICY, PRESCRIPTION, PROSCRIPTION, SINGLE PROSCRIPTION, TERMINOLOGICAL LANGUAGE POLICY, TEXT PRODUCTION, TEXT RECEPTION, VARIANTS

Opsomming: 'n Leksikografiese benadering tot taalbeleid en aanbevelings vir toekomstige woordeboeke. Taalbeleid kom op verskillende vlakke voor en tipieserwys lei die formulering daarvan tot ' $n$ preskriptiewe aanbieding van data. Leksikograwe moet in hulle woordeboeke reageer op die besluite van taalbeleidmakers. In hierdie verband kan woordeboeke bly by ' $n$ streng preskriptiewe beleid deur slegs die goedgekeurde vorme in te sluit. Woordeboeke kan ook 'n deskriptiewe verslag van taalgebruik gee sonder om aanbevelings of korrektheidsaansprake te maak. Derdens kan woordeboeke proskriptief wees deur bepaalde vorme aan te beveel, selfs al is so ' $n$ aanbeveling in stryd met die voorgeskrewe vorme. Hierdie artikel bied 'n oorsig oor verskillende vlakke van taalbeleid en die beginsels van preskripsie, deskripsie en proskripsie. Voorbeelde word gegee om sekere leksikografiese toepassings van preskripsie toe te 
lig. Daar word beklemtoon dat toegang tot relevante data belangrik vir woordeboekgebruikers is. Gevolglik word die leksikografiese toepassing van proskripsie bespreek as 'n uitvoerbare alternatief tot preskripsie. Daar word aan die hand gedoen dat proskripsie, in sy verskillende toepassingsmoontlikhede, tot 'n leksikografiese aanbieding kan lei wat die gebruiker bevoordeel en wat bydra om aan die funksies van die betrokke woordeboek te voldoen.

Sleutelwoorde: DESKRIPSIE, DIREKTE PRESKRIPSIE, DIREKTE PROSKRIPSIE, DOMEIN-SPESIFIEKE TAALBELEID, ENKELPROSKRIPSIE, INDIREKTE PRESKRIPSIE, INDIREKTE PROSKRIPSIE, KOGNITIEWE FUNKSIE, KOMPLEMENTÊRE PROSKRIPSIE, LEKSIKOGRAFIESE FUNKSIES, NASIONALE TAALBELEID, PRESKRIPSIE, PROSKRIPSIE, TAALBELEID, TEKSPRODUKSIE, TEKSRESEPSIE, TERMINOLOGIESE TAALBELEID, TOEGANG, VARIANTE, VLAKKE VAN TAALBELEID

\section{Introduction}

The official use of language, on various levels, is typically regulated by strict or less strict rules, formulated by relevant language bodies. Different types of language policies and different approaches to their implementation prevail on the different levels of policy making. A variety of terms have been introduced to refer to various related aspects (cf. Bergenholtz and Gouws 2006). Important in this regard is the distinction between language policy, as applied to the intralingual and the interlingual level, and the notion of communication policy. In this article, language policy is used as an umbrella term, referring to all the different levels of decisions and their implementation, aimed at regulating various aspects of language use, especially with regard to spelling, inflection, pronunciation and the formal recognition of words. Lexicographers have to take cognisance of the different forms of language policy relevant to the dictionaries they are compiling, and decisions need to be made regarding their response to the official decisions of language policy makers. They have to negotiate the best ways to ensure that the functions of their dictionaries can be satisfied and the genuine purpose of the dictionary can be achieved. This implies that although they may obey the rules prescribed by formal bodies in the formulation of their language policies, the user needs and functions of the dictionary may at times demand the inclusion of non-prescribed forms. Working with the distinction between prescription, description and proscription, this article hopes to make a contribution to finding a solution for the problems many lexicographers, also within the multilingual South Africa, experience when having to decide on a lexicographic response to language policy.

\section{Language policy}

Until now, much has been written about description and prescription in terms of lexicographic works. Different authors have argued in favour of one method 
or the other as relevant in dictionary making. In this respect, there is a long tradition of relating language policy at a micro level to lexicography. It is therefore surprising that only very few contributions dealing theoretically with the complex relation between language policy at a macro level and the conception of lexicographic works can be found in the existing literature. Cf. Bergenholtz and Gouws (2006) and Bergenholtz and Tarp (2007), of whom the former (Bergenholtz and Gouws 2006: 14) explicitly declares: 'Every single lexicographical decision has a language policy relevance and therefore, in the end, a political dimension'.

This statement has two dimensions: Firstly, it expresses the idea that the lexicographic decisions at the micro level, in one way or another, are related to the general language policy at the macro level. And, secondly, it indicates that the single decisions may also influence the dictionary users' specific language use. It is the first of these two dimensions that will be explored in this discussion, i.e. the relation existing between general language policy and lexicographic decisions. However, in order to discuss this relation, and for the sake of this article, it is necessary to distinguish between at least three different types of general language policy in terms of their coverage, i.e. national, domain-specific and terminological. The necessity of this distinction is due to the fact that these three types of language policy play different roles and mostly deal with different linguistic phenomena, for which reason they have different consequences for lexicography.

In this article, the term national language policy refers to the pretended regulation of use within a given speech community, whether this community is only one among others within a specific country (such as some of the African languages in South Africa), the only community in a specific country (like Denmark) or a cross-border community like the German-speaking population in Germany, Austria and Switzerland. The national language policy is normally laid down by some official or semi-official body such as a national language board or an academy and most often prescribes correct spelling and inflection forms and sometimes also pronunciation. In some language communities it even prescribes the words to be used, whereas there are no known examples of a national language policy prescribing style. The boards or academies responsible for the national language policy may enjoy different degrees of authority and there are even speech communities with competing authorities in terms of language policy.

The term domain-specific language policy refers to the language policy laid down by 'intermediate' entities such as companies, ministries, universities, local governments, and various kinds of organisations. This type of language policy may regulate the language, or languages, to be used within their sphere of influence, i.e. inside a company or in external communication. Apart from this, the domain-specific language policy most often regulates the style to be used internally and externally in the entity in question. It is normally subordinated to the national language policy, although it may prescribe specific words 
and word forms to be used, which in some cases even goes against the recommendations contained in the national language policy.

Finally, the term terminological language policy refers to the regulation of terminology within one or several specialised subject fields. This policy may be decided by a national or regional terminological board or by separate organisations, companies or other entities. In this way, it is sometimes interwoven with the domain-specific language policy and sometimes even with the national language policy. The regulation of terminology normally embraces the selection of the recommended terms and their definition.

As can be seen, the three mentioned types of language policy cover different areas and regulate different aspects of language use although they may overlap to a certain degree. This has to be taken into account when planning and compiling different types of lexicographic works. In this respect, lexicographers working with general dictionaries for communicative and cognitive purposes, in one way or another, have to relate to the national language policy; lexicographers (or terminologists) dealing with specialised dictionaries have to relate their work to the relevant terminological language policy; and lexicographers compiling company, branch and similar dictionaries have to relate to the domain-specific language policy as far as it has relevance for their work. However, just as it is important to relate to the language policy at a macro level, it is also important to determine the character of this relation, which will be discussed in subsequent paragraphs, with examples from general and specialised dictionaries. But before proceeding to this discussion, it is necessary to make a brief incursion into the field of methodology in terms of description, prescription and proscription.

\section{About the principles of prescription, description and proscription}

Prescription, description and proscription represent different methods of collecting and utilising data from different sources, like corpora, linguistic surveys, text investigations, etc. (cf. Bergenholtz 2003). In the interaction between language policy and lexicography, the principles of prescription, description and proscription play an important role. Therefore a brief discussion of these concepts is needed.

\subsection{Prescription}

By their very nature language boards or official language bodies are prescriptive. They are prescribing, e.g. by formulating the spelling rules for a given language or by acknowledging, for example, certain loan words as belonging to the standard variety of the language. Prescription is not necessarily the acknowledgement of only a single form. Quite often a language body officially recognises different variants, e.g. orthographic variants of a single word. For Afrikaans, the Afrikaanse Woordelys en Spelreëls (Afrikaans Word List and Spelling 
Rules) (Taalkommissie 2001) is the official publication of the Afrikaans Language Commission, a commission entrusted by the South African Academy for Science and Arts to formulate orthographic rules for Afrikaans. This publication presents the prescriptive decisions of the official language body. In many instances, the Afrikaans Language Commission does not give only one form but makes provision for spelling variants, e.g. the forms weer eens $\mathrm{x}$ weereens and ver $\mathrm{x}$ verr. When it comes to the writing of compounds in which one of the components is a proper noun no less than five variant forms are officially acknowledged and therefore prescribed, e.g. Kaapstadstasie, Kaapstad-stasie, Kaapstad-Stasie, Kaapstad stasie, Kaapstad Stasie. Prescription prevails on all the different levels of language policy making and can have a major influence on the language use of the relevant speech community.

Prescription strongly comes to the fore in dictionaries. Within a userdriven lexicographic approach, dictionaries are regarded as utility instruments, compiled for a well-defined target user group with specific lexicographic needs in a specific situation. Knowledgeable dictionary users see their dictionaries as practical tools to assist them in solving real problems. Their dictionary consultation should result in an optimal retrieval of information from the data on offer in the dictionary. These users rely on the dictionary to supply the needed data from which they can retrieve the needed information.

Today it is generally accepted that no dictionary can be everything to everyone. When planning dictionaries, lexicographers need to determine the function(s) of the envisaged dictionary, and every aspect of the dictionary should be planned in terms of these functions.

A brief look at dictionaries through the ages show that many lexicographic products had been compiled to display the data the lexicographer decided on - often without having identified a target user group or having taken cognisance of the needs of these users. Far too often the compilation of dictionaries has given no evidence of a functional approach. The overall impression of users had been that the lexicographer knows what should go into a dictionary, that dictionaries contain the truth, the whole truth and nothing but the truth, and that users should therefore rely on dictionaries as authoritative sources of knowledge. Authority has in many dictionaries been seen as equal to the notion of prescription, i.e. where lexicographers inform users how they should use language. This was already evident in Samuel Johnson's approach in preparing his dictionary of 1755 when he says in The Plan of a Dictionary of the English Language (1747) that 'fixing the language' was the main purpose of his dictionary. He describes his prescriptive approach as follows: 'Toleration, adoption and naturalization have run their lengths. Good order and authority are now necessary.'

When taking a prescriptive approach lexicographers impose their point of view on the dictionary and the target users of the dictionary. Many dictionary users actually want this kind of guidance, especially when consulting a dictionary for text production purposes. The dictionary should not give choices, 
indicate variants or give regional or colloquial words but should present the users with a single, pure, correct form. Different forms and degrees of prescription can be distinguished (cf. Bergenholtz 2003), and these forms will not be discussed in this article. It suffices to say that prescription, especially a strong prescriptive approach, can be regarded as either presenting a single form (with regard to, for example, orthography, pronunciation, meaning or morphological possibilities) or more than one form as the preferred form(s) of the dictionary without any reference to other words from the non-standardised use. This strong prescription implies that only these forms and words should be allowed as being correct whilst their variants or other words should be prohibited. When following a prescriptive approach the lexicographer places himself in the position of having to judge the language and make a decision regarding the accepted forms. In many instances a prescriptive dictionary will follow the rules laid down by a formal language body or entity, as referred to in the section on language policy. The dictionary will then function as an extension and an instrument at the disposal of this standardisation authority and the prescription of the relevant body is presented in the dictionary. The average dictionary user does not distinguish between different language bodies and academies but regard the dictionary as the embodiment of authority. Just as domain-specific language policy sometimes goes against the prescription of the national language policy, lexicographic prescription does not necessarily always adhere to official rules. It also prevails where lexicographers give a single form and ignore all other variants, but where the forms they give deviate from the official language rules with regard to, for example, orthography, morphology, etc. In such a case, the dictionary is not an extension of the language body but follows its own prescriptive methods.

\subsection{Description}

Description does not only reflect the decisions of an official body or the implementation of an official language policy on any of the levels discussed in a previous section of this article. Description rather endeavours to give a comprehensive account of actual language use by presenting a variety of forms, whether orthographic, morphological or pronunciation variants, or, for example, words representing dialectal, sociolectal or chronolectal variants. Description avoids classifying occurring forms as either recommended or not permissible. It reflects the spectrum of actual language use.

Although official language bodies primarily function in a prescriptive way, even they do sometimes also reflect the use of non-prescribed forms. The latest edition of the already mentioned Afrikaanse Woordelys en Spelreëls has a separate text in which a list of so-called 'Omgangsafrikaans', i.e. colloquial Afrikaans, in which words from especially the informal varieties of Afrikaans are given. They are not prescribed as correct or even presented as permissible but they have been included to represent variants and other words from regis- 
ters not formally acknowledged by the prescriptive language body. Important, however, is the fact that they have been included in a separate list - a descriptive list complementing the official prescriptive list.

Description plays a significant role in some dictionaries. A descriptive approach in lexicography sees the lexicographer trying to reflect the actual language use, making provision for different variants but without indicating a recommended form or labelling a given form as not permissible. Bergenholtz (2003) indicates different forms and degrees of description. Depending on the functions of a dictionary, a descriptive approach can either frustrate or please the users. In a dictionary compiled for text reception, a presentation of all the different variants can assist the users effectively. Users consulting a dictionary for text production or translation are often frustrated by a descriptive approach, because they do not find explicit guidance regarding the best or the proper or the most correct form. Having to make choices and being confronted with variants is not what they expect from a dictionary.

Description does not imply that all variants are on the same level of acceptability or have the same usage frequency. In some cases, differences in usage frequency are indicated but the dictionary does not commit itself to an indication of a recommended form. A too strong descriptive approach, where a variety of choices are given without an indication of a recommended form, can be frustrating to users, especially where the user is consulting the dictionary for text production purposes. The comprehensive monolingual Afrikaans dictionary the Woordeboek van die Afrikaanse Taal (Schoonees et al. 1951-) follows a descriptive approach and tries to be as consistent as possible by employing description in the presentation of different types of data, including pronunciation. Therefore it gives all the pronunciation possibilities of a given word but in this endeavour the descriptiveness often leads to the inclusion of possible instead of real forms. A strong introspective approach leads to a presentation of all possible pronunciation combinations, and these variants are listed without giving the user advice regarding the most typical forms. The article of the lemma mikro-ekonomie (English micro-economy) illustrates this problem by giving no less than eighteen pronunciation variants.

Owing to the fact that users see dictionaries as authoritative sources, even description can be interpreted by the average user as a presentation of the correct forms. Wiegand (1986) speaks about the normative force of descriptive dictionaries. Although many users do not distinguish between description, prescription and proscription, discussed in the following section, lexicographers need to take a firm decision regarding the approach to follow in their dictionaries. This decision must take cognisance of a range of implications that the opted-for approach may have on the users and the use of dictionaries and language within the given speech community.

Language bodies should be well aware of the advantages and disadvantages of both prescription and description and lexicographers need to realise that both these approaches have an influence on the success of information retrieval in a specific dictionary. 


\subsection{Proscription}

Bergenholtz (2001 and 2003) discusses the notion of proscription and the different forms and degrees of proscription but he also motivates the use of this term. He indicates that this term originates from the Latin word proscribere (to make public). Although the English word proscribe is used in the sense 'to forbid', the term proscription in lexicography does not refer to the state of being forbidden. In a proscriptive approach, the lexicographer wants to inform the user not only about language use but also about the form recommended by the lexicographer (cf. Bergenholtz 2003: 13). In lexicography, a proscriptive approach sees the lexicographer deviating from the prescriptive way of saying 'this should be done' in favour of saying 'this is recommended'. A proscriptive approach often recommends a single form but it may also give different variants or include different words, accompanied by a clear indication of the form the lexicographer recommends. In some specific cases, it could also lead to the recommendation of two or more forms. This may, for instance, be the case when these forms appear with the same frequency in a corpus or when new words or terms are introduced into a given language and the future will decide whether, for instance, a pure loan word, a transliterated word or a coined word will prevail in the speech community. However, although one or more recommended forms are given it does not imply that they are the only permissible forms. It merely represents the lexicographer's recommendation and does not necessarily have to reflect the decisions of a formal language body.

In his classification of different types of proscription, Bergenholtz (2003: 13) differentiates among others between exact proscription (where only one variant is recommended; other variants can be mentioned) and not exact proscription (where more than one variant is recommended; other variants can be mentioned). Although he refers to the possibility that other variants can be mentioned he does not distinguish a type of proscription based on the mentioning or not of non-recommended forms. Such a distinction may be useful because it contributes to the contextualization which often has an influence on the choices a user makes for a given utterance. In this article, the dichotomy single x complementary proscription refers to this distinction. A procedure of single proscription sees only the recommended form(s) included in the dictionary, whereas the recommended forms are complemented by their non-recommended variants in a procedure of complementary proscription. Complementary proscription may be restricted to the article of the lemma representing the recommended form by including the non-recommended forms as microstructural entries in that article. This is article-internal complementary proscription. Another form of complementary proscription, however, occurs when all the non-recommended words are lemmatised with cross-references from the articles of the non-recommended forms to the recommended word. This represents articleexternal complementary proscription. A similar distinction can also be introduced for prescription. 
From a language policy perspective, the notion of description does not pose many problems. Language policy is not concerned with proscription. Real problems come to the fore with regard to the notion of prescription. Consequently the discussion in this article will move away from description and will focus on prescription and the resulting problems when this approach is reflected in dictionaries. As a solution, arguments will be presented in favour of implementing a proscriptive approach.

\section{Problems in existing approaches of prescription}

\subsection{An example from the Faroe Islands}

The Faroe Islands comprise a small group of islands in the middle of the North Atlantic Ocean with a tiny population of about 50000 inhabitants. Politically, the Faroe Islands is a kind of Danish semi-colony with an extended degree of autonomy. The language spoken by the islanders is Faroese which is an independent Indo-European language with its roots in the Old Norse that came to the islands with the immigration of Norwegian Vikings starting in the 9th century.

For various historical reasons, the Faroe Islands, just as the nearby Iceland, have a strongly purist tradition with an official language policy which prescribes the words to be used in official communication. The problem, however, is that there is big and growing distance between the officially prescribed vocabulary and the vocabulary used by the ordinary people in their daily life. This is reflected both in text reception where the ordinary people may not understand, or at least fully understand, all the prescribed words, and in text production where they will frequently not know which words to use in official communication, e.g. when they approach the local authorities or apply for a job.

These types of communication problems are exactly those which dictionaries should endeavour to solve by means of the selected data. However, the existing monolingual Faroese dictionaries are not primarily planned to satisfy the real needs of the Faroese people in terms of communication, but to serve as agitation tools for the official language purists. As such, they only include the prescribed vocabulary. This approach, which blindly transfers the principles used to formulate the official language policy to lexicography creates a number of serious problems for the Faroese people when they seek assistance to solve text-reception and text-production problems.

In text reception, they will of course be able to access all the prescribed words and find an explanation of their meaning. But when it comes to the nonprescribed words used in colloquial communication, they will have no dictionary to consult as these words are not allowed and therefore not included in the existing monolingual dictionaries.

In text production, the problem is even worse. As the daily used colloquial 
words are not allowed in the dictionaries, the ordinary people will find no help at all when they have problems writing informal texts such as personal letters and various kinds of essays. Neither will they receive any assistance when they do not know which words to use in official communication. Although these words are included in the existing dictionaries, the users who do not know them have no way to access them except reading the dictionary from end to end, a time-consuming procedure which is contrary to the very idea of a dictionary as a reference work and consultation tool.

However, the ordinary people are in most cases more creative than their governors. The close relations with Denmark mean that Danish is taught as the first foreign language in the Faroese education system and that most Faroese have a relatively high proficiency level in Danish. Many Faroese with text-production problems in their mother tongue therefore use this competence to consult a bilingual Danish-Faroese dictionary which will then lead them to the prescribed Faroese word.

The same holds true when they need assistance to produce colloquial texts in their mother tongue. In this case, a bilingual English-Faroese dictionary is frequently used for looking up known English words to find the not-prescribed, but daily used Faroese words. However, the precondition for using this method is a relatively high proficiency level in English which many Faroese people lack.

In both cases, the absence of adequate monolingual Faroese dictionaries implies that in order to produce a correct or an informal, colloquial text in their mother tongue, they will have to make a long detour through a foreign language, consulting a dictionary not conceived for this purpose. The reason for this situation is the uncritical transference of principles and methods used within one sphere of human activity, i.e. the formulation of language policy, to another sphere of human activity, i.e. the making of dictionaries which should always be conceived as utility tools with the genuine purpose of meeting the real information needs of the envisaged target group. In this respect, Tarp (2008: 12) writes:

This necessary interaction with other disciplines does not mean that lexicography can automatically take over the arsenal of concepts, theories and methods used by these other disciplines. The fact that the object of study is delimited, and the fact that lexicography has its own independent core distinguishing it from other disciplines, mean that all these concepts, theories and methods must be subjected to critical analysis with a view to determining what should be rejected, what can be used, and how the useful factors can be adjusted and adapted to suit the particular nature of lexicography.

The Faroese example illustrates why the purist approach to lexicographic products can be considered to be highly problematic. On the one hand, this approach leads to dictionaries that do not satisfy the real needs of the user group, in this case the Faroese people. On the other hand, it is counterproductive even from a purist perspective. The very conception of dictionaries ac- 
cording to purely purist principles impedes the access to the prescribed words that may never or only rarely be used in real communication because people will be unable to find them and probably not know of their existence.

\subsection{Examples from South Africa}

The forms prescribed by official language boards, academies and language bodies are usually elevated to the standard variety of the given language. It is interesting to note the way in which dictionaries respond to the decisions of these bodies and the way in which language bodies respond to the decisions made by lexicographers. Dictionaries either function as extensions of these bodies by adhering rigorously to the prescription or, in a descriptive or proscriptive way, they display forms acknowledged by the official bodies as well as other forms and variants not acknowledged by the official bodies.

The response of language boards to the way in which dictionaries negotiate their prescription is not always evident. The 1984 edition of Tweetalige Woordeboek/Bilingual Dictionary (Bosman et al. 1984), a bilingual dictionary with Afrikaans and English as language pair, included lexical items as lemmas not yet acknowledged by the Afrikaans Language Commission. The items had been included on account of their usage frequency in Afrikaans. At a subsequent meeting of the Afrikaans Language Commission, one of the members lodged a formal complaint and a letter was written to the publishing house to express the dismay of the Language Commission. Here the dictionary did not wait for the Afrikaans Language Commission to acknowledge the given words but the dictionary reflected actual language use in a descriptive way.

The development of Afrikaans lexicography gives ample evidence of instances where dictionaries took a prescriptive approach (cf. Gouws and Ponelis 1992 and Gouws 1995). In the multilingual South Africa, language contact is a daily reality. Language contact necessarily leads to all languages occurring in the contact situation to be influenced by the other languages and to include borrowed forms in their lexicon. This has happened in all the South African languages, including South African English, as is clearly seen in A Dictionary of South African English on Historical Principles (Silva 1996; cf. also Gouws 1999).

An exaggerated purist approach and a persecution of Anglicisms with the consequent prescription had a detrimental influence on, among others, Afrikaans dictionaries. Bergenholtz and Gouws (2006) discuss this issue and mention that even the eighth edition of Groot Woordeboek/Major Dictionary (Eksteen et al. 1993) still included forms like bruismelk/skuimmelk/roomysmelk instead of the frequent melkskommel (for the English milkshake), knormoer instead of selfaansitter (for the English self starter) and briewebesteller instead of posman/posbode (for the English postman). The Tweetalige Woordeboek/Bilingual Dictionary omits the highly frequent Afrikaans word geboortemerk (English birthmark) in favour of the Dutch form moedervlek whilst bookmark gets the equivalents boeklêer en leeswyser but not the much used word boekmerk. These contrived forms were 
prescribed in order to avoid the use of loan translations from English. Prescription led to a gap between the dictionary and its users because the dictionary did not reflect the real language use.

The comprehensive multivolume WAT, the Woordeboek van die Afrikaanse Taal, exercises its descriptive approach among others by giving lemmas representing lexical items from all the different lects of Afrikaans. The focus is especially strong on dialectal and chronolectal variants, although borrowings also find their way into the macrostructure. Given its comprehensive nature and the limited number of Anglicisms, little criticism has been directed at this dictionary in terms of its deviation from a purist approach. Owing to the traditional prescriptive approach of many dictionaries, users came to expect prescription and a presentation of the pure and the only correct form in their dictionaries, especially dictionaries of a more restricted nature. When a number of frequently used borrowings from English were included in two editions of HAT, the Verklarende Handwoordeboek van die Afrikaanse Taal (Odendal and Gouws $2000 / 2005$ ) and this inclusion was mentioned in the preface, the majority of critical remarks was directed at the inclusion of these because the dictionary was no longer portraying pure language.

It is necessary for lexicographers to focus on the needs of their intended target users and the data these users require to ensure that the functions of the dictionary can be satisfied. New dictionary projects should take cognizance of the way in which older dictionaries, dictionary users and language bodies had responded to this issue and the influence it had on the language, the speech community and the lexicographic practice. A distinction should be made between needs as the users would traditionally interpret them and needs realized by the lexicographers in terms of the functions resulting from the userprofile. It amounts to a distinction between presumed needs and real needs. A purely prescriptive approach is often only directed at the presumed needs whereas description and proscription also account for the real needs.

For dictionaries to be compiled in the African languages of South Africa, important decisions need to be taken regarding the application and influence of a strong prescriptive approach. Nong, De Schryver and Prinsloo (2002) already discussed various issues with regard to the problem of loan words versus indigenous forms. There are frequent discussions regarding the preference given to loan words at the cost of already existing ones and the application of spelling rules and the occasional failure of dictionaries to adhere to these rules. The inclusion of coined words in dictionaries is also contentious, because of the confusion it can cause amongst members of the speech community. A dictionary like the New Sepedi Dictionary (Prinsloo and Sathekge 1996) counters these objections by explicitly indicating that it has been compiled on the basis of frequency of use.

Lexicographers are faced with challenges regarding the lemmatisation of science and technology terminology. Many of these terms are regarded as 'book terminology' that never occurs in actual language use. Dictionaries should rather display transliterated loan words instead of unnaturally formed lexical 
items. The Sesotho sa Leboa word phaekukunama, a lexical form referring to the English meat pie, was coined more than three decades ago and was included in the Northern Sotho Terminology and Orthography No. 4 (Wolff 1988) but it is not used by the speech community. (We thank Ms W.M. Mojapelo for this example.)

A similar prescriptive discrepancy between data presented in dictionaries and the forms used by members of the speech community is evident in the inclusion of lemmas like matengwa (English lottery), bofora (English fraud) and taba (English topic) in the Sepedi dictionary Pukuntšu Dictionary (Kriel 1983) instead of the forms lothari, froto and thopiki respectively, loan words used by the average members of the speech community. (We thank Prof. D.J. Prinsloo for these examples.)

The problems referred to do not only regard general language, but also specialised language and terminology. Van der Merwe (2008) mentions a number of terms which are frequently used by ordinary people but not accepted as correct terminology by the South African wine industry. One such example is the English term drinking wine (drinkwyn in Afrikaans), which in the official wine terminology has been replaced by the term wine although many ordinary wine drinkers still use drinking wine. Another example is tapvat, which is the official Afrikaans equivalent for the English term boxed wine. In this case, most ordinary people will use the colloquial bokswyn which, however, also refers to a lesser quality wine and is therefore not allowed by the industry as an Afrikaans equivalent for boxed wine. A last example is the popular word champagne, which the European Union has now restricted only to products coming from the French district of Champagne. The official term to denominate wines produced by the same method, e.g. the Cap Classique, but not coming from the French district is sparkling wine although champagne is still widely used in colloquial language. Thus, if drinkwyn, bokswyn and champagne are not included in a wine dictionary, at least as cross-reference entries, many users of this dictionary will probably not be able to find the correct terms prescribed by the wine industry.

It is clear from these examples that, similar to the situation in the Faroe Islands, the prescribed words and variants often go against the actual language use. By adhering to a prescriptive approach lexicographers can easily isolate their dictionaries from the needs of their users.

\section{Access}

As utility instruments dictionaries need to convey the type of data determined by their functions. This data is directed at satisfying the real needs of the intended target user group. Consequently dictionaries should not only be regarded as show cases of language prescription but as utility tools they should include all data necessary to fulfil their specific functions, even if this goes against or beyond the prevailing prescriptive vision. The ideal situation would prevail when the decisions of the language bodies are not isolated from the 
language used by the speech community at large. Although lexicographers have to take cognisance of the decisions of language bodies and should not endeavour to position their dictionaries in opposition to these decisions, the principles guiding these decisions may not be a dominating force when selecting data for inclusion in their dictionaries. What is included in a dictionary should assist the users in their daily communication, both in text reception and text production in the formal and less formal registers, as well as in satisfying those cognitive needs that fall within the scope of lexicographic products. In a multilingual society especially, translation is important, and dictionaries need to support their users by also employing a translation function. The title of Komensky's dictionary of 1631, Ianua Linguarum Reserata (The Gate of Tongues), portrays the assignment of the lexicographer, i.e. the compilation of a product that unlocks the gate of language for the users. When planning dictionaries, lexicographers should go even further by not only unlocking the gate of tongues but by ensuring access to the data behind the gate.

Giving access to relevant data needs to be regarded as one of the most important tasks of a lexicographer. Access to 'relevant data' is not guaranteed if the lexicographer regards that specific data entry in isolation. Contextualisation of data is paramount and in dictionaries this contextualisation often implies not isolating a word from its variants. Access to a given word can often best be achieved via a variant. In their discussion of a dictionary of gene technology, Bergenholtz, Kaufmann and Tarp (1994) refer to an example where a purely prescriptive approach would have impeded the access of users to specific forms. The Spanish equivalent for the English form $D N A$ is $A D N$. However, evidence from a Spanish corpus shows that in $40 \%$ of the instances the English form $D N A$ is used. Although the Spanish equivalent $A D N$ may be both the recommended and the prescribed form successful access to this form will often depend on the inclusion of the English loan form DNA as a separate lemma of which the treatment can be restricted to a cross-reference entry, guiding the user to $A D N$. A purely prescriptive approach would have led to the inclusion of only the prescribed form $A D N$. The omission of the loan form $D N A$ would have impeded the access of many users to the recommended form. The best possible access to the lemma $A D N$ can be achieved by means of article-external complementary proscription procedures. The importance of including both $A D N$ and $D N A$ in the dictionary can also be motivated on practical grounds. If only one form is included a user, not familiar with the other form, may encounter the form omitted from the dictionary in the literature. While so many different acronyms are being used in the scientific field this user may regard the encountered form as a wholly different acronym not related to the form included in the dictionary.

In order to ensure optimal access to the lemma representing the recommended lexical item, lexicographers should not only look at recommended and recognised forms but also at forms that are not allowed and even forms representing frequently made spelling mistakes. For example, users often consult a dictionary to retrieve the meaning of a given word or its translation equivalent, 
not realising that they are misspelling the word. If the specific spelling mistake is a very frequent one, the chances are good that different dictionary users would try to access the treatment of the given word via the incorrect form, cf. the inclusion of the article of the lemma akceptere in Den Danske Ordbog (Hjorth and Kristensen 2003-2006):

akceptere vb. - alm. stavefejl for $\rightarrow$ acceptere.

[akceptere vb. - a frequent misspelling of $\rightarrow$ acceptere.]

Here the lemma is not presented in bold, like the other lemmas in this dictionary. In this way a distinction is made between the allowed and the non-allowed spelling variants. Omitting such a misspelled form from the dictionary will impede the access of many users to the required data. When endeavouring to achieve optimal access, lexicographers should aim to present as many relevant forms as possible. They should include allowed but non-recommended forms as well as not allowed words and words representing typical spelling mistakes, i.e. not allowed and therefore also not recommended words that still occur frequently in language use. Such an inclusion and the resulting treatment (cf. the remarks made in paragraph 6 of this article) will ensure the satisfaction of the need that prompted the dictionary consultation but it will also see the user getting access to and being informed of the correct spelling of the given word. This additional access possibility may lead to a bonus in the information retrieval process.

The forms recommended in a proscriptive dictionary may be words, e.g. words from the standard or a non-standard variety, but also orthographic or inflectional variants. For some of the South African languages, the relevant language boards focus in their prescription merely on forms from one dialect, eschewing the rest (cf. Mojela 2007). When employing a more comprehensive inclusion approach a dictionary will still give a recommended word but the words from other dialects or registers will also be included as lemmas and their treatment will guide the user to the lemma representing the recommended form. This also applies to orthographic variants where the variants are separated in the alphabetical ordering of lemmas. Access between a recommended and non-recommended form does not only go via the outer access routes, i.e. that part of the access process leading a user to the required lemma. When it comes to orthographical variants where the alphabetical ordering does not separate the forms and, especially, in the case of inflectional variants, the inner access route will guide a user between the different forms. Where there are different inflectional variants, for example, the internal ordering of the variants is important to ensure the required access in order to reach the recommended form but also take cognisance of the other forms. One way of differentiating between the recommended and non-recommended forms is by ordering the recommended before the non-recommended. The use of notes (cf. paragraph 6) will place an additional emphasis on the distinction. On an article-internal level, access to the non-recommended form will then always go via the recommended form. 
In spite of the prescription of language bodies, lexicographers should realise that their users need access to relevant data. Even if the lexicographer agrees with the decisions of a prescriptive body, the lexicographic presentation should make allowance for different points of departure and different access routes in the access process of different users, for example by including the prescribed Sepedi form Hlakola (English February) as well as the frequently used form Feberware. Many users may try accessing the dictionary via a non-prescribed form and a strict adherence to the prescriptive principle, informing users that only the given form(s) should be used, would then result in unsuccessful dictionary consultation. The inclusion of as many relevant forms as possible will ensure that access to the recommended form, which might or might not be the prescribed form, can succeed by employing more than one possible access route.

\section{Presentation}

Once the non-prescribed (not allowed) or non-proscribed (not recommended) words and orthographic and inflectional variants have been included in the lemma list in order to prepare user-friendly access routes, the next question that arises is how to treat and present these words and variants as well as their prescribed or proscribed counterparts. As mentioned above, Bergenholtz (2003) operates with various degrees of prescription and proscription. In the following, this idea will be taken a step further and systematised on the basis of a distinction between the mentioned degrees of prescription and proscription as well as their differentiated treatment in different types of dictionary articles. Such a systematisation is necessary not only in order to develop lexicographic theory in this respect, but also to give useful advice and recommendations to lexicographic practice.

\subsection{How to present the non-prescribed and non-proscribed forms}

As to the non-prescribed or non-proscribed words and variants which are selected as lemmas in order to provide quick and easy access to their prescribed or proscribed counterparts, there are at least five possible types of treatment which, at the same time, represent various degrees of prescription or proscription, namely:

(a) Not giving a note addressed to the lemma,

(b) Giving a note indicating that the variant is not allowed or recommended,

(c) Giving a note indicating that the variant is frequently used, but not allowed or recommended,

(d) Giving a note indicating that the variant is not allowed, but recommended, for example because it is frequently used, and 
(e) Giving a note indicating that the variant is not allowed in formal or scientific language, but may be used in colloquial language.

It is possible to make a further subdivision in various directions but for the purpose of this contribution this typology is sufficient. Each type can now be considered separately:

(a) As the selected variants form part of the access route to the prescribed or proscribed forms, it is presupposed that some sort of cross-reference to these forms is provided in each instance. This means that the first example is a pure cross-reference article which does not have any prescriptive or proscriptive value in itself.

Bergenholtz (2003) divides prescription into open and hidden. In his definition, an open prescription requires that the prescriptive value of the data provided is explained somewhere in the dictionary, for example in the users' guide, whereas a hidden prescription is not explained at all. However, it is also necessary to distinguish between information found in the users' guide (or elsewhere in the outer matter) about the prescriptive, and proscriptive, value of the lexicographic data - among them the cross-references - and the same information retrieved from data provided in the respective dictionary articles. In this article, these two different ways of providing this information will be called direct and indirect prescription and proscription respectively.

Thus, because many users may not read the users' guide or remember its indications, they will probably in many cases not understand the prescriptive or proscriptive value of the cross-reference, i.e. why they are referred to another lemma. For this reason, it could be recommended to use direct prescription and proscription and add more data in order to assist the user, even when the information extracted from this additional data is not relevant for the dictionary function, e.g. text production, in the strict sense of the word.

(b) In the second type, the data required above are addressed to the lemma. These data can be presented in various ways, for example as it has been done in the Danish-English Genteknologisk ordbog (Bergenholtz and Kaufmann 1992) which among its functions includes text production for mother-tongue speakers of Danish:

fermentere $<\mathrm{vb}>$ ferment $<\mathrm{vb}>$

Fermentere er en ældre betegnelse for at gære

[Fermentere is an old term for gære]

Here the user is informed that the verb fermentere is no longer used in Danish specialised language dealing with molecular biology and has been replaced by gære which is actually a common Danish word, also used in colloquial communication. In this way, the user is tactfully and indirectly recommended to use the term gære in modern specialised language dealing with molecular biology. 
(c) In the third type, the user acquires the additional information that the nonprescribed or non-proscribed form is frequently used. One such example is taken from the Danish monolingual production dictionary Den Danske Netordbog (Bergenholtz et al. 2008):

liniere verbum <-r, -de, - rt $>$

Dansk Sprognævn godtager ikke denne skrivemåde, selvom den er mere end 25 gange så hyppig som den tilladte form med j, dvs. linjere.

$\rightarrow$ linjere

[The Danish Language Board does not accept this spelling although it is more than 25 times as frequent as the allowed form with $\mathrm{j}$, i.e. linjere.]

An analogous example can be provided in Sepedi. In the New Sepedi Dictionary, various variants have been included although they are considered incorrect by the Northern Sotho Terminology and Orthography No. 4 (Wolff 1988) which contains the official spelling rules of Standard Sepedi compiled by the former Sepedi Language Board. One of these non-official variants is thekesi where the correct form should be taxi. (We thank Prof. M.J. Mojalefa for this information.) In order to help guide users who only know thekesi, to the prescribed form, an article such as the following would be useful:

thekesi

The Sepedi Language Board does not accept this variant although it is frequently used in existing texts and colloquial language.

$\rightarrow$ taxi

(d) In the three previous cases, the treatment of the cross-reference lemma has been the same in terms of prescriptive and proscriptive dictionaries. In the third type, proscription prevails and recommends a given form against the prescriptive indications of the official language policy, frequently supported by a corpus analysis showing that the recommended form is much more commonly used than the officially prescribed form. The following example of this method is also taken from Den Danske Netordbog:

curriculum vitae substansiv <et; -et, -, -ene>

Dansk Sprognævn godtager ikke denne skrivemåde, men kun curriculum vitæ. Denne ordbog anbefaler curriculum vitae, da det er den normale skrivemåde i danske tekster.

[The Danish Language Board does not accept this spelling, but only curriculum vitx. However, this dictionary recommends curriculum vitae as it is the normal spelling in Danish texts.]

(e) The fifth type is a variant of the former. In this case, a distinction is made between formal or scientifically correct language, on the one hand, and informal, colloquial language on the other. One such example can be found in the English-Spanish Encyclopedic Dictionary of Gene Technology (Bergenholtz et al. 1998) where the user finds the information that the expression DNA digestion is 
not a term in the strict sense of the word, but laboratory jargon used instead of the much more complex expression hydrolysis of peptide bonds in proteins or phosphodiester bonds in nucleic acids:

DNA digestion digestión $\mathrm{f}$ del AND

The expression digestion means hydrolysis of peptide bonds in proteins or phosphodiester bonds in nucleic acids in laboratory jargon.

\subsection{How to present the prescribed and proscribed forms}

As to the words and variants prescribed or proscribed by the body responsible for the national, domain-specific or terminological language policy and selected as lemmas, there are at least five possible types of treatment:

(a) Not giving a note with reference to the non-allowed or non-recommended variants,

(b) Giving a note indicating the non-allowed or non-recommended variants,

(c) Giving a note indicating that the non-allowed or non-recommended variants are frequently used,

(d) Giving a note recommending the non-prescribed variants, and

(e) Giving a note recommending the non-prescribed variants in colloquial language.

With reference to the discussion above, it is important to remember that no word selected as a lemma is in itself either prescribed or proscribed if this value is not directly stated in the article or indirectly mentioned, i.e. somewhere else in the dictionary. On this basis, the following comments can be made:

(a) In most cases, the prescribed and proscribed variants are the only existing forms and it is therefore neither possible nor relevant to include a note about non-allowed or non-recommended variants. However, it is surprising to see that even if there are other non-prescribed or non-proscribed variants, some of which are also selected as cross-reference lemmas, these variants are not mentioned in the prescribed or proscribed articles of the majority of existing dictionaries. It is difficult to guess the reason for this decision, but it may be because the lexicographers think that the inclusion of 'non-desired' variants may confuse users who should only know about the prescribed or proscribed forms. However, the opposite argument could also be used. Users who have accessed the lemma in question through a non-allowed or non-recommended form may need confirmation that the found lemma actually corresponds to and has the same meaning as the one they first looked up, especially if the spelling differs much. This problem is especially big in electronic dictionaries where the users who enter a non-allowed or non-recommended variant in the search 
machine are frequently guided directly to the prescribed and proscribed form. This is for instance the case with the official Danish orthographic dictionary Retskrivningsordbogen (Dansk Sprognævn 2006) compiled by the Danish Language Board in order to announce its decisions regarding correct spelling and inflection. If users enter the frequently used, but non-allowed variant curriculum vitae, they will be guided directly to the following article:

curriculum vitæ $s b$., -et, curriculum vitæ, bf. pl. -ene (fork.: CV el. cv).

Users who need information about inflection for text-production purposes may not even notice that the spelling is different from the one used to access the article, and in the subsequent text production they may repeat the spelling variant which the official Danish Language Board considers to be incorrect, but which they themselves consider the right one. It should therefore be recommended that electronic dictionaries include notes giving information that the prescribed or proscribed form is different from the one users entered into the search machine. The same holds true for direct orthographic mistakes which users may not be aware of.

(b) In the second type of treatment, the dictionary informs, in one way or another, that there are other variants than the recommended or allowed ones. For instance, the problem mentioned above could easily be solved in the following way:

curriculum vitæ $s b$., -et, curriculum vitæ, bf. pl. -ene (fork.: CV el. cv).

NB: You wrote curriculum vitae which is an incorrect spelling.

(c) In some cases, it could also be relevant to inform users that the non-allowed or non-recommended form is frequently used. An example which includes a note giving information about the frequent use of a non-allowed form is provided by the Danish Music Dictionary Musikordbogen (I. Bergenholtz 2006):

akkordeon

et harmonika-instrument

[...]

Ved søgning på nettet ser det ud, som om betegnelsen med to c'er, som ikke anerkendes af Dansk Sprognævn, som regel bruges af konservatorierne i beskrivelsen af deres uddannelser, mens de to k'er ses i tekster fra musikskoler, hjemmesider mv.

[Searching on the internet, it seems that the spelling with two c's, which is not allowed by the Danish Language Board, is usually used by the academies of music in the description of their training programmes, while the two k's are used in texts from music schools, home pages, etc.]

This article follows the official spelling rules laid down by the Language Board and, at the same time, indicates that a different spelling is frequently used by 
academies of music. In this way it assists users who may be confused because they have met or only know the non-allowed spelling variant accordeon which is also frequently used by musicians.

(d) Sometimes the lexicographers decide, for some reason or other, to go against the official language policy and recommend a non-allowed variant. This is mostly the case when this variant is much more frequently used than the recommended one. An example of this type has already been provided with the Danish curriculum vitae in point (d) of paragraph 6.1.

(e) In other cases, it could be relevant to recommend the variant prescribed by the language board for use in official and formal language and another nonallowed variant to be used in informal and colloquial language. No example of this practice has been found, but it could be relevant in order to solve problems related to specific language communities, for example the problems regarding the big difference between the official and the informal language on the Faroe Islands.

\subsection{How to present inflectional variants of the same word}

In some languages, such as Danish and Afrikaans, the official language policy permits two or more inflectional patterns to the same word. This is for instance the case with the Danish verb fnise (English giggle) where the Danish Language Board permits three past tenses (fnisede, friste, fnes) and two past participles (fniset, fnist) as can be seen in the following article from its official orthographic dictionary Retskrivningsordbogen:

fnise $v b$., -ede $e l$. -te $e l$. fnes, fniset $e l$. fnist.

This descriptive way of presenting the allowed inflectional forms may be acceptable in text reception when users just want to confirm that they have found the right lemma or in cognitive situations where users need general information about the word and its morphological pattern. However, in the case of text production, this way of presenting the data may confuse users because they have to choose between several inflectional variants which may not have the same frequency in daily language use. This problem can be solved by means of a proscriptive approach as the one followed by Den Danske Netordbog which is a dictionary conceived for text production:

\footnotetext{
fnise verbum <-r, -de, -t>

Dansk Sprognævn godtager også fniste/fnes, fnist.

[The Danish Language Board also allows fniste/fnes, fnist.]
}

With this proscriptive method, Den Danske Netordbog recommends the most frequently used inflectional forms (fniser, fnisede, fniset) - which the users who 
are most often in a hurry can use immediately without reading the rest of the article - and at the same time indicates that the official language policy also allows other variants which users may prefer for stylistic or other reasons.

More than one inflectional possibility is also allowed for some Afrikaans words. In the Afrikaanse Woordelys en Spelreëls, the Language Commission allows two plural forms for many nouns ending in -ing, i.e. to add either an -e or an -s as can be seen in an example like onderskeiding (English distinction) and its plural forms onderskeidinge/onderskeidings. Both the $-e$ and the $-s$ plural forms have a high usage frequency and could be recommended in a proscriptive dictionary. However, there are other inflectional variants officially acknowledged by the Language Commission where there are definite differences in usage frequency. For nouns like musikus (English musician) and fisikus (English physicist) the plural forms musikusse/musici and fisikusse/fisici are acknowledged although the forms musici and fisici are much more frequent. This should be indicated in a dictionary with a proscriptive approach, e.g.:

fisikus (fisici) ...

Die Taalkommissie laat ook fisikusse as meervoudsvorm toe.

[The Language Commission also allows fisikusse as plural form.]

In terms of user-friendliness, such a proscriptive approach should always be recommended in dictionaries conceived to assist users in solving problems related to text production.

\section{Conclusion}

The formulation of language policy typically leads to the prescription of those forms recognised by the official language body as being correct or pure. Prescription states which forms should be used, excluding the use of all other forms. Description presents a variety of forms without differentiating between accepted and non-accepted, recommended and non-recommended, whereas proscription offers one or more recommended forms. Different types of proscription prevail and the application of certain types can also lead to an indication of the non-recommended forms.

This article emphasizes the importance of a distinction between different levels of language policy and the implications that decisions on these different levels have for lexicographers. Lexicographers need to deal with the prescription by official language bodies but can only give a thorough lexicographic account of language if they respond to the needs of their intended users and the envisaged functions of their dictionaries. In order to be able to do this, this article proposes that lexicographers should take cognisance of prescriptive decisions by language bodies but in their dictionaries they should venture beyond the prescriptive visions. By being proscriptive lexicographers make recommendations to their users and often these recommendations coincide 
with the decisions prescribed by various official language bodies. Where the needs of dictionary users and the functions of a dictionary demand a deviation from the prescribed forms, lexicographers may recommend the non-prescribed forms that would best serve the purpose of their dictionary. Access to the recommended forms is important and where non-recommended forms, forms that are not allowed and even forms representing frequently made spelling mistakes are also included in a dictionary, it gives users additional access routes to the recommended forms.

Examples of the rigorous application of a prescriptive approach in dictionaries, a discussion of access problems and possibilities and examples of the application of proscription and the subsequent lexicographic presentation lead to the concluding recommendation of this article. Relevant data presentation, the best possible access to the data, an optimal retrieval of information and the satisfaction of the lexicographic functions of a dictionary are paramount to ensure successful dictionary use. To achieve this, lexicographers should not merely abide by the results of prescription. Dictionaries could do better by offering a wider selection of forms, complemented by well-motivated recommendations in order to guarantee the success of dictionaries as utility tools.

\section{Literature}

\section{Dictionaries}

Bergenholtz, H. and U. Kaufmann (Eds.). 1992. Genteknologisk ordbog. Dansk-engelsk/engelsk-dansk molekylærbiologi og DNA-teknologi. Copenhagen: Gads Forlag.

Bergenholtz, H. and U. Kaufmann (Eds.). 1998. Encyclopedic Dictionary of Gene Technology. EnglishSpanish. Toronto: Lugus.

Bergenholtz, H. et al. (Eds.). 2008. Den Danske Netordbog [online]. Odense: Ordbogen.com. http://www.ordbogen.com/opslag.php?\&dict=ddno [18 June 2008].

Bergenholtz, I. (Ed.). 2006. Musikordbogen [online]. Aarhus: Aarhus School of Business. http:// www.musikordbogen.dk [18 June 2008].

Bosman, D.B. et al. (Eds.). 1984'. Tweetalige Woordeboek / Bilingual Dictionary. Cape Town: Tafelberg.

Dansk Sprognævn. 2006. Retskrivningsordbogen på nettet [online]. Copenhagen: Dansk Sprognæun. http://www.dsn.dk [18 June 2008].

Eksteen, L.C. 199714. Groot Woordeboek Afrikaans-Engels/Engels-Afrikaans / Major Dictionary Afrikaans-English/English-Afrikaans. Cape Town: Pharos.

Hjorth, E. and K. Kristensen (Eds). 2003-2006. Den Danske Ordbog. Volume 1-6. Copenhagen: Gyldendal.

Johnson, S. 1755. A Dictionary of the English Language. London: J. \& P. Knapton/T. \& T. Longman et al.

Komensky, A. 1631. Ianua Linguarum Reserata.

Kriel, T.J. 1983. Pukuntšu Dictionary. Pretoria: J.L. van Schaik.

Odendal, F.F. and R.H. Gouws (Eds.). 20004/20055. Verklarende Handwoordeboek van die Afrikaanse Taal. Johannesburg: Perskor/Cape Town: Pearson Education. 
Prinsloo, D.J. and B.P. Sathekge. 1996. New Sepedi Dictionary. Pietermaritzburg: Shuter and Shooter.

Schoonees, P.C. et al. (Eds.). 1951-. Woordeboek van die Afrikaanse Taal. Pretoria: Government Printer/Stellenbosch: Bureau of the WAT.

Silva, P. (Ed.). 1996. A Dictionary of South African English on Historical Principles. Oxford: Oxford University Press.

Taalkommisie van die S.A. Akademie. 2001. Afrikaanse Woordelys en Spelreëls. Kaapstad: Pharos.

Wolff, H. 1988. Northern Sotho Terminology and Orthography No. 4. Pretoria: Government Printer.

\section{Other literature}

Bergenholtz, H. 2001. Proskription, oder: So kann man dem Wörterbuchbenutzer bei Textproduktionsschwierigkeiten am ehesten helfen. Lehr, A. et al. (Eds.). 2001. Sprache im Alltag: 499-520. Berlin/New York: De Gruyter.

Bergenholtz, H. 2003. User-oriented Understanding of Descriptive, Proscriptive and Prescriptive Lexicography. Lexikos 13: 65-80.

Bergenholtz, H. and R.H. Gouws. 2006. How to Do Policy with Dictionaries. Lexikos 13: 13-45.

Bergenholtz, H., U. Kaufmann and S. Tarp. 1994. Vore mænd i Havanna: Udarbejdelse af konception til en spansk-engelsk genteknologisk ordbog. Hermes, Journal of Linguistics 13: 291-304.

Bergenholtz, H. and S. Tarp. 2007. Politik und Sprachpolitik in der Lexikographie. Gottlieb, H. and J.E. Mogensen (Eds.). 2007. Dictionary Visions, Research and Practice: 217-240. Amsterdam: John Benjamins.

Gouws, R.H. 1995. Dictionaries and the Dynamics of Language Change. Kachru, B. (Ed.). 1995. Culture, Ideologies and the Dictionary: 297-313. Tübingen: Max Niemeyer.

Gouws, R.H. 1999. Situating a Dictionary of South African English on Historical Principles within a More Comprehensive Lexicographic Process. Lexikos 9: 269-282.

Gouws, R.H. and F.A. Ponelis. 1992. The Development of Afrikaans and the Lexicographic Tradition. Zgusta, L. (Ed.). 1992. History, Languages and Lexicographers: 77-104. Tübingen: Max Niemeyer.

Johnson, S. 1747. The Plan of a Dictionary of the English Language. Facsimile Edition 1970. Menston: The Scholar Press.

Mojela, V.M. 2007. Standardization or Stigmatization? Challenges Confronting Lexicography and Terminography in Sesotho sa Leboa. Lexikos 18: 119-130.

Nong, S., G.-M. de Schryver and D.J. Prinsloo. 2002. Loan Words versus Indigenous Words in Northern Sotho: A Lexicographic Perspective. Lexikos 12: 1-20.

Tarp, S. 2008. Lexicography in the Borderland between Knowledge and Non-Knowledge. Tübingen: Max Niemeyer.

Van der Merwe, M.F. 2008. Wine and Words: A Trilingual Wine Dictionary for South Africa. Lexikos 18: 337-348.

Wiegand, H.E. 1986. Von der Normativität deskriptiver Wörterbücher. Zugleich ein Versuch zur Unterscheidung von Normen und Regeln. Henne, H. (Ed.). 1986. Sprachnormen in der Diskussion. Beitrage vorgelegt van Sprachfreunden: 72-101. Berlin/New York: De Gruyter. 